\title{
Influence of different heat treatments on the content of phenolic acids and their derivatives in selected fruits
}

Dominik SzWAJgieR*, Tomasz HALINOWSKI, Ewa HeLmAN, Katarzyna TYLus, Aleksandra TYMcio

Dept. Biotechnol., Hum. Nutr. Sci. Food Commod.,

Univ. Life Sci. Lublin,

8 Skromna Str., 20-704 Lublin, Poland,

dszwajgier@hotmail.com
${ }^{*}$ Correspondence and reprints

Received 9 April 2013 Accepted 1 July 2013

Fruits, 2014, vol. 69, p. 167-178 (C) 2014 Cirad/EDP Sciences All rights reserved

DOI: 10.1051/fruits/2014004 www.fruits-journal.org

RESUMEN ESPAÑOL, p. 178
Influence of different heat treatments on the content of phenolic acids and their derivatives in selected fruits.

Abstract - Introduction. A considerable number of positive effects after the consumption of fruits has been pointed out in the past: hypolipidemic action, reduction of blood glucose levels, hepatoprotection and improvement of the antioxidant status as well as, inter alia, antioxidant, antiradical, anti-inflammatory, anticancer and anti-adipogenic status. Materials and methods. The changes in the levels of phenolic acids and their derivatives in fresh as well as in processed fruits (chokeberry, wild strawberry, apples var. Idared and Champion, cherry, apricot, peach, raspberry, cranberry, and bilberry) were studied using HPLC with UV detection. Dried fruit homogenates and compotes were produced. Also, fruits were fried to simulate jam production. Results and discussion. Eleven phenolic acids and their derivatives were identified in tested samples: caffeic, chlorogenic, p-coumaric, ferulic, gallic, ellagic, protocatechuic, p-hydroxybenzoic, gentisic, syringic and vanillic acids. In most cases, the thermal processing of fruits caused a decrease in the levels of phenolic acids. In some preserves, the level of selected individual phenolic compounds was unchanged or was significantly increased. Conclusion. It can be concluded that thermal processing can have a differential effect on the levels of phenolic acids in preserves and general conclusions could not be formulated. The fruit composition in which a phenolic acid is present can play a role in this context.

Poland / fruits / canned fruits / jams / compotes / phenolic compounds / phenolic content

Influence de différents traitements thermiques sur la teneur en acides phénoliques de fruits sélectionnés.

Résumé - Introduction. Un grand nombre d'effets positifs de la consommation de fruits a été déjà mis en évidence : action hypolipidémique, réduction du taux de glucose dans le sang, hépatoprotection, amélioration de l'état antioxydant ainsi que, entre autres, effets antioxydant, antiradicalaire, anti-inflammatoire, anti-cancéreux ou anti-adipogénique. Matériel et méthodes. Les changements des taux d'acides phénoliques et de leurs dérivés dans certains fruits (aronia, fraise des bois, pommes var. Idared et Champion, cerise, abricot, pêche, framboise, canneberge et myrtille) frais ou transformés ont été étudiés par HPLC et détection UV. Des homogénats de fruits séchés et de compotes ont été effectués. En outre, les fruits ont été cuits pour simuler la production de confitures. Résultats et discussion. Onze acides phénoliques et dérivés ont été identifiés dans des échantillons testés : acides caféique, chlorogénique, p-coumarique, férulique, gallique, ellagique, protocatéchique, p-hydroxybenzoïque, gentisique, syringique et vanillique. Dans la plupart des cas, le traitement thermique des fruits a provoqué une diminution des taux d'acides phénoliques. Dans certaines conserves, le taux de composés phénoliques individuels est resté inchangé ou a été considérablement augmenté. Conclusion. Le traitement thermique pourrait avoir des effets différentiés sur les taux d'acides phénoliques dans les fruits transformés et il n'est pas possible de généraliser ces effets. Dans ce contexte, la composition des fruits contenant un acide phénolique peut varier.

Pologne / fruits / conserve de fruits / confiture / compote / composé phénolique / teneur en phénols 


\section{Introduction}

Edible fruits exhibit antioxidant and antiradical activities, as has been repeatedly pointed out in the past [1-3]. Other positive effects of fruit consumption include hepatoprotection by chokeberry (Aronia melanocarpa) fruit [4] and peach (Prunus armeniaca) fruit [5]. Also, chokeberry fruit exhibit hypolipidemic action, reduce blood glucose levels (metabolic syndrome), improve the antioxidant status of experimental rats [6, 7], exert an antiproliferative effect on Caco-2 cancer cells [8], prevent gastric mucosal damage and inhibit the oxidative stress in mucosa [9]. Bilberry (Vaccinium myrtillus) and cranberry ( $V$. macrocarpon) fruits protect mitochondria by a decrease in the cytochrome c-enhanced oxidation of 6-hydroxydopamine [10]. Cranberry fruit exhibit antiproliferative properties against colon cancer cells [11] and cancer chemopreventive properties by induction of quinone reductase (phase II xenobiotic detoxification enzyme) [12]. Cherry (Prunus cerasus) fruit exhibit antioxidant and anti-inflammatory activity in mice [13]. Raspberry (Rubus idaeus) fruit, a very rich source of phenolic compounds [14], exert anti-adipogenic [15], antioxidant, anti-inflammatory and anticancer activity (colon, breast, lung and gastric human tumor cells) [15-17]. Also, apples have previously been pointed out as a source of a wide range of different phenolic compounds, including phenolic acids [18].

Phenolic acids are well known in vitro and in vivo antioxidants [19, 20] and are, inter alia, anti-inflammatory [21], anticarcinogenic [22] and anti-platelet aggregation [23] agents. It has also been shown that phenolic acids normalize a considerable number of blood parameters [24-30]. The anticancer activity [31] and the protection of hepatocytes by phenolic acids [32, 33] has also been pointed out. Last but not least, the neuroprotection of phenolic acids has been proved in numerous in vitro and in vivo studies [34-38].

Thermal processing of fruits causes a decrease in the levels of phenolic compounds [39-42]. A limited number of studies have studied the effect of thermal processing on the levels of phenolic acids in preserves made from pears [43], raspberries [44-47], pomegranates [48], strawberries [45, 47, 49], blackberries, blueberries [45], apricots, apples [50], cherries and wild blueberries [47]. However, a considerable number of popular fruits have not yet been studied in this context. Given the numerous health benefits to be derived from the consumption of fruits, our study was designed in order to determine the influence of heat treatment on the levels of individual phenolic acids in selected fruit preserves. It is obvious that the fruits studied in this work contain very differentiated levels of individual phenolic acids. However, our aim was to study how the heat treatment influences the percent loss of phenolic acids, regardless of whether the fruit is a rich or a poor source of these compounds.

\section{Materials and methods}

\subsection{Chemicals and fruits}

Phenolic acids (HPLC grade) were purchased from Sigma-Aldrich (Poznań, Poland). Other reagents (HPLC grade) were purchased from P.O.Ch. (Gliwice, Poland).

Black chokeberry (Aronia melanocarpa), wild strawberry (Fragaria vesca), cherry (Prunus cerasus) and raspberry ( $R u$ bus idaeus) fruits were cultivated on a farm located at 66A Kopernika Street, Bełżyce,

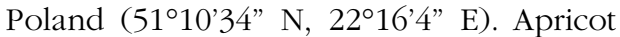
(Prunus armeniaca) and peach (P. persica) fruits were harvested from a farm located at 1 Dubieckiego Street, Lublin, Poland (5114'29” N, 22²9'48” E). Apples (Malus domestica) var. Idared and Champion, cranberry (Vaccinium macrocarpon), and bilberry ( $V$. myrtillus) were obtained from the Partnership Wholesale Market S.A. located at 65 Elizówka Street, Ciecierzyn, Poland ( $\left.51^{\circ} 17^{\prime} 17^{\prime \prime} \mathrm{N}, 22^{\circ} 34^{\prime} 49^{\prime \prime} \mathrm{E}\right)$. The identity of fruit samples was authenticated by Prof. Dr Hab. Kazimierz Głowniak from the Department of Pharmacognosy with Medicinal Plants Laboratory, Medical University of Lublin, Chodźki 1, Lublin, Poland. 


\subsection{Fruit preserves}

Compotes were produced by dipping the thawed fruit in boiling water $(1: 1, \mathrm{w} / \mathrm{w})$ until the moment that the whole sample was boiled. Shortly after the boiling had started, the whole sample was directly placed in jars, which were tightly closed. Before the extraction of phenolic acids, the whole sample was taken out of the jars, homogenized and freeze-dried at $-50{ }^{\circ} \mathrm{C}$ for 12-24 h (FreeZone 2.5 system, Labconco, USA). Simulation of jam production was performed by the heating of a portion of the thawed fruit $(30 \mathrm{~g})$ for $60 \mathrm{~min}$ in a kitchen pot with intensive mixing. Every $10 \mathrm{~min}$, an aliquot of the pulp was taken followed by freeze-drying as described above. Dried fruit homogenates were produced by the heating of the homogenized fresh fruits in a conveyor dryer (in the presence of air) in the form of a thin layer (1-3 mm) at (105 \pm 2) ${ }^{\circ} \mathrm{C}$ for $12 \mathrm{~h} \mathrm{[52]}$. Each preserve was produced in duplicate. HPLC determination of phenolic acids was performed directly after the production of the preserves.

\subsection{Determination of the dry mass of samples}

The drying was performed by the method of Qian et al. [52], with some modifications. The sample was finely ground in a laboratory mortar; a 1-g portion of the fresh fruit was accurately weighed (with a precision of $0.001 \mathrm{~g})$ and dried at $(105 \pm 2){ }^{\circ} \mathrm{C}$ for $24 \mathrm{~h}$. The sample was then weighed and dried again until the change in the weight was less than $0.005 \mathrm{~g}(1-2 \mathrm{~h})$. The analysis was performed in duplicate.

\subsection{Hydrolysis and extraction of phenolic acids}

The method proposed by Häkkinen et al. [51] was used with slight modifications. The accurately weighed freeze-dried sample $(0.5 \mathrm{~g})$ was mixed with $15 \mathrm{~cm}^{3}$ of double ionized water (DDI) water (containing $80 \mathrm{mg}$ of ascorbic acid), $25 \mathrm{~cm}^{3}$ of $96 \%$ (v/v) methanol and $10 \mathrm{~cm}^{3}$ of $6 \mathrm{~mol} \cdot \mathrm{dm}^{-3}$ $\mathrm{HCl}$. Then, the solution was purged using oxygen-free $\mathrm{CO}_{2}$ (the gas was also in the headspace of the tube) and the sample was sonicated (Sonics Vibra-Cell, 80\% amplitude/50 sec pulses and $50 \mathrm{sec}$ off, total time $2 \mathrm{~min}$ ). The flask was wrapped in aluminum foil and the solution was gently shaken (100 rpm, $35^{\circ} \mathrm{C}, 16 \mathrm{~h}$, Infors Minitron shaker, Switzerland). The extract was then filtered $(0.45-\mu \mathrm{m}$ cellulose filters). A volume of $15 \mathrm{~cm}^{3}$ of the filtrate was evaporated to dryness $\left(35^{\circ} \mathrm{C},-0.09 \mathrm{MPa}\right)$, followed by the addition of $1.5 \mathrm{~cm}^{3}$ of $99.8 \%(\mathrm{v} / \mathrm{v})$ methanol. Directly prior to HPLC, the sample was filtered (Acrodisc LC13 PVDF Gelman Sciences M1, $0.45 \mu \mathrm{m}$ ). The levels of phenolic acids were expressed according to the dry mass of the sample. For each sample, hydrolysis and extraction for HPLC were repeated twice.

\subsection{HPLC-UV analysis of phenolic acids}

The HPLC-UV system consisted of two Smartline 100 pumps, a loop $\left(0.1 \mathrm{~cm}^{3}\right)$, a dynamic mixer and a Retriever 500 fraction collector (Knauer, Germany). Separations were performed using a Symmetry C18 column $(5-\mu \mathrm{m}$ particles, $4.6 \mathrm{~mm} \times 250 \mathrm{~mm})$ coupled with a Symmetry C18 precolumn (5-um particles, $8.0 \mathrm{~mm} \times 20 \mathrm{~mm}$ ) (Waters, Ireland). Signals were recorded at $260 \mathrm{~nm}$, $280 \mathrm{~nm}, 320 \mathrm{~nm}$ or $365 \mathrm{~nm}$ using a Linear 200 UV-VIS detector (USA) coupled to an Interface IF-2 (Knauer, Germany). Chromatographic data were analyzed using EuroChrom Basic Edition ver. 3.05 (Knauer). The mobile phase consisted of DDI water $+1 \%$ $(\mathrm{v} / \mathrm{v})$ of glacial acetic acid (A) and 50\% $(\mathrm{v} / \mathrm{v})$ acetonitrile in DDI water (B). The gradient $\left(1 \mathrm{~cm}^{3} \cdot \mathrm{min}^{-1}\right)$ ran in the following manner: $0-5 \min 3 \% \rightarrow 5 \% \mathrm{~B}, \quad 5-10 \mathrm{~min}$ $5 \% \rightarrow 8 \% \mathrm{~B}, 10-15 \min 8 \% \rightarrow 13 \% \mathrm{~B}, 15-19 \mathrm{~min}$ $13 \% \rightarrow 19 \%$ B, 19-47 min 19\% $\rightarrow 40 \%$ B, 47-64 $\min \quad 40 \% \rightarrow 65 \% \quad \mathrm{~B}, \quad 64-65 \mathrm{~min}$ $65 \% \rightarrow 80 \%$ B, 65-66 min 80\% $\rightarrow 98 \%$ B, 66$69 \min 98 \%$ B, 69-72 $\min 98 \% \rightarrow 3 \%$ B. The laboratory reproducibility of the method for ferulic acid (within-laboratory standard deviation within 1 month of the studies) was in the range of $3.5-7.0 \%$. Intra-day repeatability and reproducibility of the HPLC method, calculated using HPLC standards of 
Table I.

Levels of total phenolic acids (ng. $\mathrm{g}^{-1}$ dry matter) in fruits and their corresponding preserves.

\begin{tabular}{|c|c|c|c|c|c|c|c|c|}
\hline \multirow[t]{2}{*}{ Fruit } & \multirow[t]{2}{*}{ Fresh fruit } & \multirow[t]{2}{*}{ Compote } & \multicolumn{6}{|c|}{$\begin{array}{l}\text { Duration of fruit heating for jams } \\
\text { (min) }\end{array}$} \\
\hline & & & 10 & 20 & 30 & 40 & 50 & 60 \\
\hline Apple var. Idared & $68 \pm 4 d$ & $54 \pm 9 \mathrm{~cd}$ & $58 \pm 7 \mathrm{bcd}$ & $38 \pm 6 \mathrm{abcd}$ & $33 \pm 6 a b c$ & $32 \pm 5 a b c$ & $23 \pm 4 a b$ & $20 \pm 3 a$ \\
\hline Apple var. Champion & $51 \pm 5 b$ & $18 \pm 2 a$ & $25 \pm 3 a$ & $27 \pm 2.0 \mathrm{a}$ & $21 \pm 3.0 \mathrm{a}$ & $12 \pm 4 a$ & $12 \pm 4 a$ & $11 \pm 2 a$ \\
\hline Apricot & $31 \pm 5 a$ & $35 \pm 5 a$ & $27 \pm 3 a$ & $34 \pm 2 a$ & $32 \pm 6 a$ & $26 \pm 3 a$ & $17 \pm 3 a$ & $24 \pm 4 a$ \\
\hline Bilberry & $87 \pm 8 a$ & $56 \pm 6 a$ & $57 \pm 7 a$ & $58 \pm 6 a$ & $55 \pm 3 a$ & $66 \pm 4 a$ & $68 \pm 6 a$ & $70 \pm 7 \mathrm{a}$ \\
\hline Black chokeberry & $183 \pm 19 c$ & $158 \pm 19 b c$ & $108 \pm 17 \mathrm{abc}$ & $109 \pm 8 \mathrm{abc}$ & $100 \pm 15 a b$ & $104 \pm 5 a b$ & $79 \pm 8 a$ & $74 \pm 8 a$ \\
\hline Cherry & $92 \pm 7 c$ & $73 \pm 5 b c$ & $61 \pm 3 a b c$ & $50 \pm 6 a$ & $59 \pm 5 a b$ & $55 \pm 4.0 \mathrm{ab}$ & $48 \pm 6 a$ & $36 \pm 6 a$ \\
\hline Cranberry & $9 \pm 2 a$ & $8 \pm 3 a$ & $7 \pm 1 \mathrm{a}$ & $6 \pm 1 a$ & $6 \pm 2 a$ & $6 \pm 1 \mathrm{a}$ & $4 \pm 1 a$ & $4 \pm 1 a$ \\
\hline Peach & $88 \pm 6 d$ & $65 \pm 8 c$ & $35 \pm 3 b$ & $22 \pm 2 b$ & $7 \pm 2 a$ & $3 \pm 1 \mathrm{a}$ & $1 \pm 0 \mathrm{a}$ & $1 \pm 0 \mathrm{a}$ \\
\hline Raspberry & $1381 \pm 71 \mathrm{c}$ & $967 \pm 161 b c$ & $784 \pm 102 a b$ & $598 \pm 54 \mathrm{ab}$ & $540 \pm 40 a b$ & $437 \pm 47 a$ & $473 \pm 37 a$ & $455 \pm 31 \mathrm{a}$ \\
\hline Wild strawberry & $214 \pm 22 c$ & $162 \pm 27 b c$ & $119 \pm 16 \mathrm{ab}$ & $105 \pm 10 \mathrm{ab}$ & $87 \pm 9 a b$ & $98 \pm 9 a b$ & $66 \pm 10 a$ & $76 \pm 8 a b$ \\
\hline
\end{tabular}

In each row, different letters denote a significant difference at $p<0.05$.

vanillic, caffeic, chlorogenic and p-coumaric acids, were below $6.0 \%$ and were acceptable for this study.

\subsection{Statistical analysis}

Mean values with standard deviations were calculated. Tukey's HSD test (STATISTICA 8.0, StatSoft, Inc., USA) was used for the determination of statistical differences with the significance denoted at $p<0.05$. Each sample was studied in four repeats (each preserve was produced in duplicate, and, from each duplication, hydrolysis and extraction for HPLC were repeated twice).

\section{Results and discussion}

\subsection{Total content of phenolic acids in fruit preserves}

The heating of apples (var. Idared and Champion), chokeberry, cherry, peach, raspberry and wild strawberry fruits caused a significant reduction of the total phenolic acid levels in compotes and/or in "jams" (table I). The decrease in total phenolic acids in compotes was 0-65\%, in comparison with the corresponding fresh-frozen (thawed) fruits. The loss of total phenolic acids in "jams" after $60 \mathrm{~min}$ of heating ranged from approximately $20 \%$ to $99 \%$, in comparison with the levels in corresponding fresh-frozen (thawed) fruits. In samples produced from apricot, bilberry and cranberry, no significant loss of total phenolic acids was observed, although a decrease in the sum of phenolic acids in absolute terms was seen in the case of these three fruits and corresponding compotes and "jams".

\subsection{Content of individual phenolic acids in fruit preserves}

It is worth noting that the total level of phenolic acids was significantly decreased at different stages of the heating, depending on the fruit. This phenomenon was most probably caused by differences in the amounts of individual phenolic acids in fruits (the "phenolic acid profile" of fruits). Therefore, the amounts of individual phenolic acids were also analyzed in this project because we suspected that phenolic acids may present differentiated thermostability. Eleven phenolic acids and their derivatives were detected in the test samples: caffeic, 
chlorogenic, p-coumaric, ferulic, gallic, vanillic, protocatechuic, p-hydroxybenzoic, gentisic, syringic and ellagic acids (tables II$I V)$. In most cases, the thermal processing of fruits caused a decrease in the levels of individual phenolic acids. However, the influence of thermal processing on the amounts of individual phenolic acids was unclear. The most dramatic loss of phenolic acids was predominantly observed in the case of "jams" heated for $60 \mathrm{~min}$, in comparison with the thawed fruit. However, in the case of selected "jam" samples, no significant loss of the following phenolic acids was observed after 60 min of heating: caffeic (cranberry, bilberry), chlorogenic (apricot), p-coumaric (wild strawberry, apricot), ferulic (raspberry, cranberry) gallic (raspberry, apricot), gentisic (raspberry), syringic (chokeberry, apple var. Idared, cherry) and ellagic acids (bilberry) (tables $I I-I V$ ). In the case of cherry "jam", the levels of ellagic acid were significantly increased in samples heated for 30-60 $\mathrm{min}$, in comparison with the fresh cherry fruit (table IV). However, the increase in ellagic acid was an exception and, in most cases, a loss of phenolic acids was observed in the "jams" studied in our work. It is known that ellagic acid can be released from ellagitannins and its proportion can be elevated in a preserve in comparison with fresh fruit [46]. Last but not least, a significant $(p<0.05)$ decrease in the levels of the following phenolic acids was observed in dried fruit homogenates in comparison with fresh fruits (table V): $\mathrm{p}$ hydroxybenzoic acid (chokeberry); caffeic, chlorogenic and syringic acids (cherry); caffeic, p-coumaric and syringic acids (raspberry). However, the levels of the rest of the phenolic acids detected in dried fruit homogenates were not significantly decreased after drying $(p<0.05)$. The content of ellagic acid in a dried homogenate was increased in comparison with fresh fruit $(p<0.05)$.

The degradation of some phenolic acids can yield other phenolic acids, e.g., the hydrolysis of chlorogenic acid elevates the level of caffeic acid in the product. Spanos and Wrolstad observed an increase in caffeic acid levels due to its release from chlorogenic acid during the thermal processing of fruits [43]. Indeed, there was a statistically confirmed loss of chlorogenic acid in compotes and/or in "jams" produced from apple (var. Idared), cherry, peach and raspberry pulps, whereas in the case of apricot no significant loss of chlorogenic acid was observed (table II). However, in our study the loss of caffeic acid due to the heating of the fruit surpassed the in situ release of caffeic acid from chlorogenic acid in "jams" produced from apple (var. Idared), cherry and peach.

The changes in the levels of phenolic acids and their derivatives during the heat treatment of fruits studied in our paper were unclear. Other authors have obtained similar results to those presented below. Unfortunately, in many studies the duration of the heating and some other parameters of the production of fruit preserves were not given. In the study by Spanos and Wrolstad [43], a high temperature-short time process $\left(89^{\circ} \mathrm{C}\right.$, $90 \mathrm{~s})$ as well as the pasteurization of pear juice in bottles $\left(85^{\circ} \mathrm{C}, 2 \mathrm{~min}\right)$ caused an increase in the levels of chlorogenic acid and coumaroylquinic acid, whereas the level of caffeic acid and coumaric acid was either decreased or unchanged. Vacuum concentration $\left(60^{\circ} \mathrm{C}\right)$ caused the hydrolysis of chlorogenic acid and coumaroylquinic acid. Nevertheless, a net loss of coumaric acid was observed in selected samples [43]. Diffusion extraction (at $63^{\circ} \mathrm{C}$ ) and vacuum evaporation (at $86^{\circ} \mathrm{C}$ ) caused, respectively, a considerable elevation and the loss of ellagic acid and its derivatives in raspberry juice (in comparison with high-speed centrifugation) [44]. In the study of Zafrilla et al., the levels of ellagic acid, its 4-arabinoside, 4 '(4"-acetyl)-arabinoside and 4' (4"'-acetyl)xyloside were not much affected by thermal processing similar to that applied during the industrial production of raspberry jam ( $78^{\circ} \mathrm{C} \rightarrow 92^{\circ} \mathrm{C} \rightarrow 88^{\circ} \mathrm{C}$, filling of the jar) [46]. A higher amount of ellagic acid, ellagic acid glucosides and total ellagic derivatives was observed in pomegranate juice produced after heat treatment in comparison with juice produced from fresh, non-heated fruit or from fruit subjected to freezing at $-20^{\circ} \mathrm{C}$ [48]. On the other hand, Häkkinen et al. highlighted a $20 \%$ loss of ellagic acid in strawberry jam (produced by cooking the 


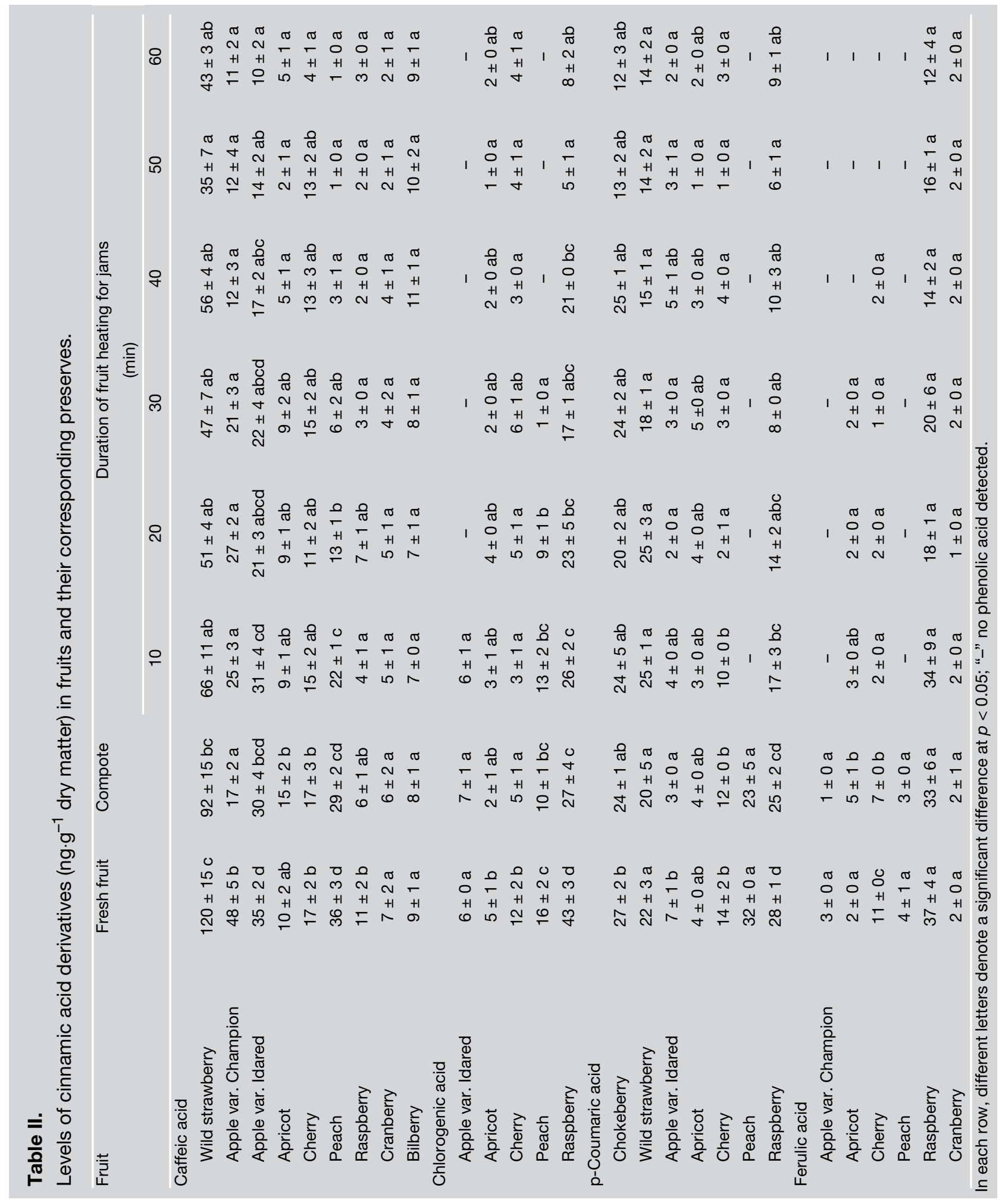




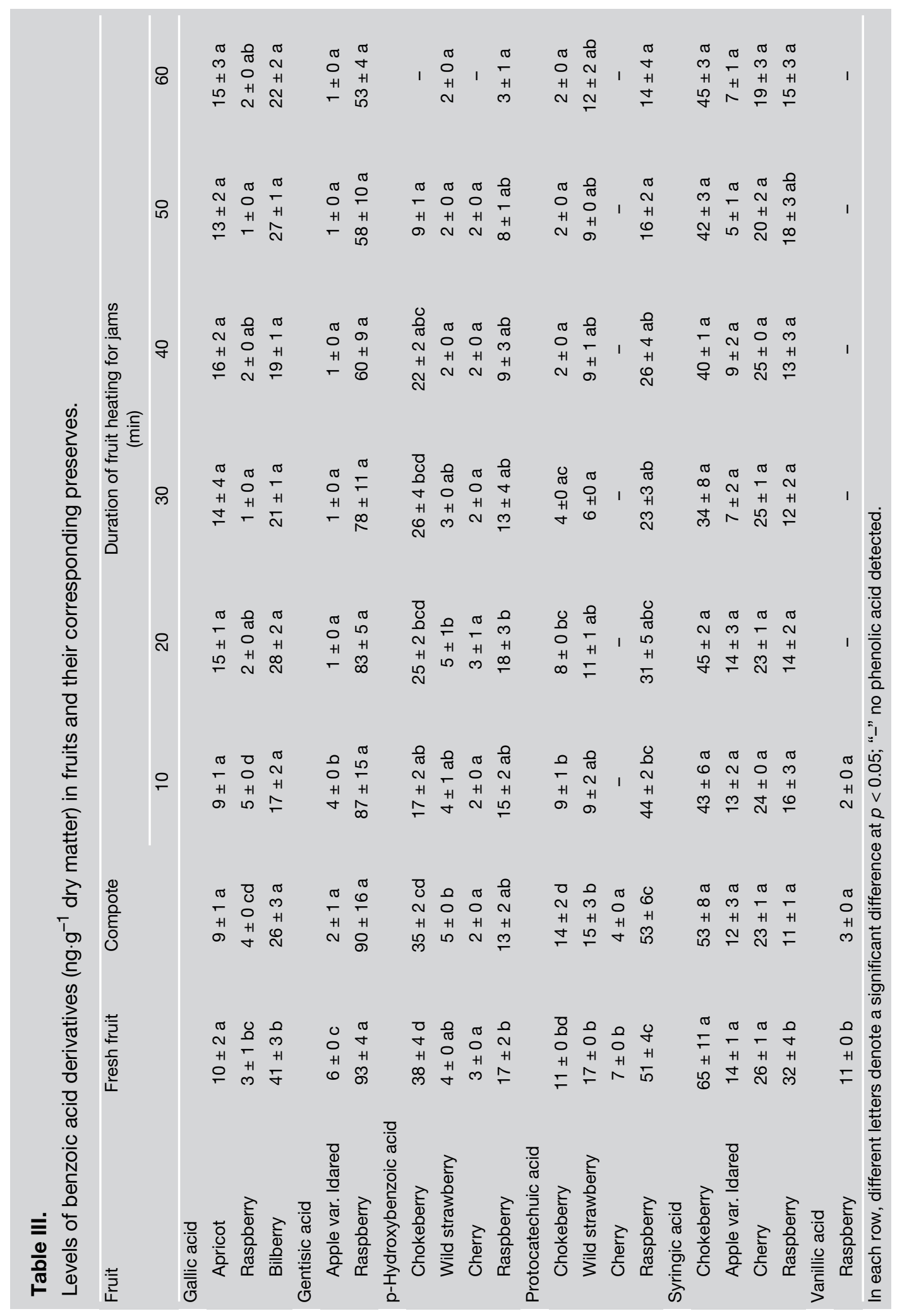




\begin{tabular}{|c|c|c|c|c|c|c|c|c|}
\hline \multirow[t]{2}{*}{ Ellagic acid } & \multirow[t]{2}{*}{ Fresh fruit } & \multirow[t]{2}{*}{ Compote } & \multicolumn{6}{|c|}{$\begin{array}{l}\text { Duration of fruit heating for jams } \\
\text { (min) }\end{array}$} \\
\hline & & & 10 & 20 & 30 & 40 & 50 & 60 \\
\hline Chokeberry & $42 \pm 2 b$ & $32 \pm 6 b$ & $15 \pm 3 a$ & $11 \pm 2 a$ & $12 \pm 1 a$ & $15 \pm 1 a$ & $13 \pm 2 a$ & $15 \pm 2 a$ \\
\hline Wild strawberry & $51 \pm 4 c$ & $30 \pm 4 b$ & $15 \pm 1 \mathrm{a}$ & $13 \pm 1 \mathrm{a}$ & $13 \pm 1 \mathrm{a}$ & $16 \pm 3 a$ & $6 \pm 1 \mathrm{a}$ & $5 \pm 1 \mathrm{a}$ \\
\hline Cherry & $2 \pm 0 \mathrm{a}$ & $3 \pm 0 \mathrm{ab}$ & $5 \pm 0$ abcd & $4 \pm 0 a b c$ & $7 \pm 1 \mathrm{~cd}$ & $6 \pm 1 \mathrm{bcd}$ & $8 \pm 1 d$ & $6 \pm 1 \mathrm{bcd}$ \\
\hline Raspberry & $1055 \pm 46 c$ & $702 \pm 123 b$ & $534 \pm 65 a b$ & $388 \pm 30 a$ & $365 \pm 13 a$ & $280 \pm 23 a$ & $343 \pm 18 a$ & $326 \pm 12 a$ \\
\hline Bilberry & $37 \pm 4 a$ & $22 \pm 2 \mathrm{a}$ & $33 \pm 5 a$ & $23 \pm 3 a$ & $26 \pm 1 \mathrm{a}$ & $36 \pm 2 a$ & $31 \pm 3 a$ & $39 \pm 4 a$ \\
\hline
\end{tabular}

\section{Table V.}

Levels of phenolic acids (ng. $\mathrm{g}^{-1}$ dry matter) in dried homogenates prepared from fresh fruit.

$\begin{array}{lccccccc}\text { Fruit } & \text { Caffeic acid } & \text { Chlorogenic acid } & \text { p-Coumaric acid } & \text { Ellagic acid } & \text { Gallic acid } & \text { p-Hydroxybenzoic acid } & \text { Syringic acid } \\ \text { Chokeberry } & - & - & - & - & - & - & 13 \pm 2 \\ \text { Wild strawberry } & 40 \pm 2 \mathrm{~b} & - & 9 \pm 1 \mathrm{~b} & - & - & - & - \\ \text { Cherry } & 8 \pm 1 \mathrm{a} & 6 \pm 1 & 1 \pm 0 \mathrm{a} & 5 \pm 1 & - & - & 9 \pm 2 \mathrm{a} \\ \text { Raspberry } & 4 \pm 0 \mathrm{a} & - & 14 \pm 2 \mathrm{~b} & - & - & - & 6 \pm 2 \mathrm{a} \\ \text { In each column, different letters denote a significant difference at } p<0.05 . & \end{array}$

fruit for $30 \mathrm{~min}$ ) in comparison with fresh fruit [49]. Similarly, Levaj et al. demonstrated a considerable loss of ellagic acid in jams produced from sour cherry, strawberry, raspberry and wild blueberry [47]. Amakura et al. observed unambiguous results concerning the free and total levels of ellagic acid as well as caffeic acid in blackberry, raspberry, blueberry and strawberry jams in comparison with the corresponding fresh fruits [45]. The results concerning the levels of phenolic acids in raw apricots and apples, their purees, and apricot nectars and jams obtained by Dragovic-Uzelac et al. were also not unequivocal [50]. For example, the levels of chlorogenic acid were similar in the three varieties of apricots and in their corresponding purees. However, a significant decrease was observed in the amount of chlorogenic acid during the production of puree from apples (var. Idared). The levels of caffeic acid and p-coumaric acids decreased in apples (var. Idared) puree and in selected apricot purees (but not in all). The levels of ferulic acid were reduced in all apricot purees in comparison with the corresponding fruits. In the same study it was shown that the levels of chlorogenic acid, caffeic acid, p-coumaric acid and ferulic acid were reduced in apricot nectars and jams in comparison with the corresponding fruits. Also, Levaj et al. observed a considerable loss of phenolic acids (chlorogenic, caffeic, gallic and p-hydroxybenzoic acids) in jams in comparison with fresh sour cherry, strawberry, raspberry and blueberry fruits [47].

\section{Conclusions}

Our results showed that elevated temperature caused changes (predominantly a decrease) in the levels of individual phenolic acids but only in selected products. The content of some phenolic acids was not changed or was elevated. The level of the individual phenolic acid in some products was significantly decreased, whereas in 
other preserves, the level of the same phenolic acid was not changed. Therefore, it can be concluded that the loss of phenolic acids is ambiguous and the evolution of the levels of these compounds during the thermal processing of different fruits cannot be subject to a single explanation. The results we obtained were probably influenced by the composition of the fruit as well as by the processing procedure (water content, temperature of the process, the oxygen access during the intensive mixing of a fruit, etc.). Therefore, compote and jam production should be thoroughly studied taking into consideration these factors.

\section{Acknowledgment}

This scientific study was supported by the Ministry of Science and Higher Education of the Republic of Poland (Scientific Grant no. 2339/B/P01/2010/38) and by the Scientific Project POIG 01.01.02-00-061/09.

\section{References}

[1] Zhang L., Li J., Hogan S., Chung H., Welbaum G.E., Zhou K., Inhibitory effect of raspberries on starch digestive enzyme and their antioxidant properties and phenolic composition, Food Chem. 119 (2010) 592599.

[2] Roussos P.A., Sefferou V., Denaxa N.-K., Tsantili E., Stathis V., Apricot (Prunus armeniaca L.) fruit quality attributes and phytochemicals under different crop load, Sci. Hortic. 129 (2011) 472-478.

[3] Caillet S., Côté J., Doyon G., Sylvain J.-F., Lacroix M., Antioxidant and antiradical properties of cranberry juice and extracts, Food Res. Int. 44 (2011)1408-1413.

[4] Valcheva-Kuzmanova S., Borisova P., Galunska B., Krasnaliev I., Belcheva A., Hepatoprotective effect of the natural fruit juice from Aronia melanocarpa on carbon tetrachloride-induced acute liver damage in rats, Exp. Toxicol. Pathol. 56 (2004) 195-201.

[5] Yurt B., Celik I., Hepatoprotective effect and antioxidant role of sun, sulphited-dried apricot (Prunus armeniaca L.) and its kernel against ethanol-induced oxidative stress in rats, Food Chem. Toxicol. 49 (2011) 508513.

[6] Valcheva-Kuzmanova S., Kuzmanov K., Mihova V., Krasnaliev I., Borisova P., Belcheva A., Antihyperlipidemic effect of Aronia melanocarpa fruit juice in rats fed a high-cholesterol diet, Plant Food. Hum. Nutr. 62 (2007) 19-24.

[7] Jurgoński A., Juśkiewicz J., Zduńczyk Z., Ingestion of black chokeberry fruit extract leads to intestinal and systemic changes in a rat model of prediabetes and hyperlipidemia, Plant Foods Hum. Nutr. 63 (2008) 176-182.

[8] Bermùdez-Soto M.J., Larrosa M., GarciaCantalejo J., Espin J.C., Tomás-Barberan F.A., Garcia-Conesa M.T., Transcriptional changes in human Caco-2 colon cancer cells following exposure to a recurrent nontoxic dose of polyphenol-rich chokeberry juice, Genes Nutr. 2 (2007) 111-113.

[9] Valcheva-Kuzmanova S., Marazova K., Krasnaliev I., Galunska B., Borisova P., Belcheva A., Effect of Aronia melanocarpa fruit juice on indomethacin-induced gastric mucosal damage and oxidative stress in rats, Exp. Toxicol. Pathol. 56 (2005) 385-392.

[10] Yao Y., Vieira A., Protective activities of Vaccinium antioxidants with potential relevance to mitochondrial dysfunction and neurotoxicity, Neurotoxicology 28 (2007) 93-100.

[11] Vu K.D., Carlettini H., Bouvet J., Côté J., Doyon G., Sylvain J.-F., Lacroix M., Effect of different cranberry extracts and juices during cranberry juice processing on the antiproliferative activity against two colon cancer cell lines, Food Chem. 132 (2012) 959-967.

[12] Caillet S., Lorenzo G., Côté J., Doyon G., Sylvain J.-F., Lacroix M., Cancer chemopreventive effect of fractions from cranberry products, Food Res. Int. 45 (2012) 320-330.

[13] Šarić A., Sobočanec S., Balog T., Kušić B., Šverko V., Dragović-Uzelac V., Levaj B., Čosič Z., Mačak Šafranko Ž., Marotti T., Improved antioxidant and anti-inflammatory potential in mice consuming sour cherry juice (Prunus cerasus cv. Maraska), Plant Foods Hum. Nutr. 64 (2009) 231-237.

[14] Castilho Maro L.A., Pio R., Santos Guedes M.N., Patto de Abreu C.M., Nogueira Curi P., Bioactive compounds, antioxidant activity and mineral composition of fruits of raspberry cultivars grown in subtropical areas in Brazil, Fruits 68 (2013) 209-217.

[15] Mejia-Meza E.I., Yáňez J.A., Remsberg C.M., Takemoto J.K., Davies N.M., Rasco B., 
Clary C., Effect of dehydration on raspberries: polyphenol and anthocyanin retention, antioxidant capacity, and antiadipogenic activity, J. Food Sci. 75 (2010) H5-H12.

[16] Bowen-Forbes C.S., Zhang Y., Nair M.G., Anthocyanin content, antioxidant, antiinflammatory and anticancer properties of blackberry and raspberry fruits, J. Food Compos. Anal. 23 (2010) 554-560.

[17] Juranic Z., Zizak Z., Tasic S., Petrovic S., Nidzovic S., Leposavic A., Stanojkovic T., Antiproliferative action of water extracts of seeds or pulp of five different raspberry cultivars, Food Chem. 93 (2005) 39-45.

[18] Jakopic J., Slatnar A., Stampar F., Veberic R., Simoncic A., Analysis of selected primary metabolites and phenolic profile of 'Golden Delicious' apples from four production systems, Fruits 67 (2012) 377-386.

[19] Young J., Wahle K.W.J., Boyle S.P., Cytoprotective effects of phenolic antioxidants and essential fatty acids in human blood monocyte and neuroblastoma cell lines: Surrogates for neurological damage in vivo, Prostag. Leukotr. Ess. 78 (2008) 145-159.

[20] Itagaki S., Kurokawa T., Nakata C., Saito Y., Oikawa S., Kobayashi M., Hirano T., Esiki K., In vitro and in vivo antioxidant properties of ferulic acid, A comparative study with other natural oxidation inhibitors, Food Chem. 114 (2009) 466-471.

[21] Fernández M.A., Sáenz M.T., García M.D., Anti-inflammatory activity in rats and mice of phenolic acids isolated from Scrophularia frutescens, J. Pharm. Pharmacol. 50 (1998) 1183-1186.

[22] Van der Logt E.M., Induction of rat hepatic and intestinal UDP-glucuronosyltransferases by naturally occurring dietary anticarcinogens, Carcinogenesis 24 (2003) 1651-1656.

[23] Yasuda T., Inhibitory effects of urinary metabolites on platelet aggregation after orally administering Shimotsu-To, a traditional Chinese medicine, to rats, J. Pharm. Pharmacol. 55 (2003) 239-244.

[24] Balasubashini M.S., Rukkumani R., Viswanathan P., Menon, V.P., Ferulic acid alleviates lipid peroxidation in diabetic rats, Phytother. Res. 18 (2004) 310-314.

[25] Jung E.H., Kim S.R., Hwang I.K., Ha T.Y., Hypoglycemic effects of a phenolic acid fraction of rice bran and ferulic acid in C57BL/KsJ-db/db mice, J. Agric. Food Chem. 55 (2007) 9800-9804.
[26] Suzuki A., Yamamoto, M., Jokura, H., Fujii, A., Tokimitsu, I., Hase, T., Saito, I., Ferulic acid restores endothelium-dependent vasodilation in aortas of spontaneously hypertensive rats, Am. J. Hypertens. 20 (2007) 508-513.

[27] Adisakwattana S., Moonsan P., YibchokAnun S., Insulin-releasing properties of a series of cinnamic acid derivatives in vitro and in vivo, J. Agric. Food Chem. 56 (2008) 7838-7844.

[28] Fetoni A.R., Mancuso C., Eramo S.L.M., Ralli M., Piacentini R., Barone E., Paludetti G., Troiani D., In vivo protective effect of ferulic acid against noise-induced hearing loss in the guinea-pig, Neuroscience 169 (2010) 1575-1588.

[29] Duchnowicz P., Broncel M., Podsędek A., Koter-Michalak M., Hypolipidemic and antioxidant effects of hydroxycinnamic acids, quercetin, and cyanidin 3-glucoside in hypercholesterolemic erythrocytes (in vitro study), Eur. J. Nutr. 51 (4) (2012) 435-443.

[30] Bolling B.W., Ji L.L., Lee C.-H., Parkin K.L., Dietary supplementation of ferulic acid and ferulic acid ethyl ester induces quinine reductase and gluthatione-S-transferase in rats, Food Chem. 124 (2011) 1-6.

[31] Mori H., Kawabata K., Yoshimi N., Tanaka T., Murakami T., Okada T., Murai H., Chemopreventive effects of ferulic acid on oral and rice germ on large bowel carcinogenesis, Anticancer Res. 19 (5A) (1999) 3775-3778.

[32] Liu C.L., Wang J.M., Chu C.Y., In vivo protective effect of protocatechuic acid on tertbutyl hydroperoxide-induced rat hepatotoxicity, Food Chem. Toxicol. 40 (2002) 635641.

[33] Srinivasan M., Sudheer A.R., Pillai K.R., Kumar P.R., Sudhakaran P.R., Menon V.P., Influence of ferulic acid on gamma-radiation induced DNA damage, lipid peroxidation and antioxidant status in primary culture of isolated rat hepatocytes, Toxicology 228 (2006) 249-258.

[34] Wenk G.L., McGann-Gramling K., HaussWegrzyniak B., Ronchetti D., Maucci R., Rosi S., Gasparini L., Ongini E., Attenuation of chronic neuroinflammation by a nitric oxidereleasing derivative of the antioxidant ferulic acid, J. Neurochem. 89 (2004) 484-493.

[35] Cho J.Y., Kim H.S., Kim D.H., Yan J.J., Suh H.W., Song D.K., Inhibitory effects of long-term administration of ferulic acid on astrocyte activation induced by intracerebroventricular injection of beta-amyloid 
peptide (1-42) in mice, Prog. Neuro- Psychopha. 29 (2005) 901-907.

[36] Karakida F., Ikeya Y., Tsunakawa M., Yamaguchi T., IkarashiY., TakedaS., Aburada M., Cerebral protective and cognition-improving effects of sinapic acid in rodents, Biol. Pharm. Bull. 30 (2007) 514-519.

[37] Cheng C.Y., Su S.Y., Tang N.Y., Ho T.Y., Chiang S.Y., Hsieh C.L., Ferulic acid provides neuroprotection against oxidative stress-related apoptosis after cerebral ischemia/reperfusion injury by inhibiting of ICAM-1 mRNA expression in rats, Brain Res. 13 (2008) 136-150.

[38] Yabe T., Hirahara H., Harada N., Ito N., Nagai T., Sanagi T., Yamada H., Ferulic acid induces neural progenitor cell proliferation in vitro and in vivo, Neuroscience 165 (2010) 515-524.

[39] Khanal R.C., Howard L.R., Prior R.L., Effect of heating on the stability of grape and blueberry pomace procyanidins and total anthocyanins, Food Res. Int. 43 (2010) 14641469.

[40] Côté J., Caillet S., Doyon G., Dussault D., Salmieri S., Lorenzo G., Sylvain J.-F., Lacroix M., Effects of juice processing on cranberry antioxidant properties, Food Res. Int. 44 (2011) 2907-2914.

[41] Rababah T.M., Al-Mahasneh M.A., Kilani I., Yang W., Alhamad M.N., Ereifej K., Al-u'datt $M$., Effect of jam processing and storage on total phenolics, antioxidant activity, and anthocyanins of different fruit, J. Sci. Food Agric. 91 (2011) 1096-1102.

[42] Arancibia-Avila P., Namiestnik J., Toledo F., Werner E., Martinez-Alaya A.L., RochaGuzmán N.E., Gallegos-Infante J.A., Gorinstein S., The influence of different time durations of thermal processing on berries quality, Food Control 26 (2012) 587-593.

[43] Spanos G.A., Wrolstad R.E., Influence of variety, maturity, processing, and storage on the phenolic composition of pear juice, J. Agric. Food Chem. 38 (1990) 817-824.
[44] Rommel A., Wrolstad R.E., Ellagic acid content of red raspberry juice as influenced by cultivar, processing, and environmental factors, J. Agric. Food Chem. 41 (1993) 19511960.

[45] Amakura Y., Umino Y., Tsuji S., Tonogai Y., Influence of jam processing on the radical scavenging activity and phenolic content in berries, J. Agric. Food Chem. 48 (2000) 6292-6297.

[46] Zafrilla P., Ferreres F., Tomás-Barberán F.A., Effect of processing and storage on the antioxidant ellagic acid derivatives and flavonoids of red raspberry (Rubus idaeus) jams, J. Agric. Food Chem. 49 (2001) 3651-3655.

[47] Levaj B., Dragović-Uzelac V., Delonga K., Kovačevič Ganič K., Banovi M., Bursač Kovačevič D., Polyphenols and volatiles in fruits of two sour cherry cultivars, some berry fruits and their jams, Food Technol. Biotechnol. 48 (2010) 538-547.

[48] Gil M.I., Tomás-Barberán F.A., Hess-Pierce B., Holcroft D.M., Kader A.A., Antioxidant activity of pomegranate juice and its relationship with phenolic composition and processing, J. Agric. Food Chem. 48 (2000) 4581-4589.

[49] Häkkinen S.H., Kärenlampi S.O., Mykkänen H.M., Heinonen I.M., Törrönen A.R., Ellagic acid content in berries: Influence of domestic processing and storage, Eur. Food Res. Technol. 212 (2000) 75-80.

[50] Dragovic-Uzelac V., Pospišil J., Levaj B., Delonga K., The study of phenolic profiles of raw apricots and apples and their purees by HPLC for the evaluation of apricot nectars and jams authenticity, Food Chem. 91 (2005) 373-383.

[51] Häkkinen S., Heinonen M., Kärenlampi S., Mykkänen H., Ruuskanen J., Törrönen R., Screening of selected flavonoids and phenolic acids in 19 berries, Food Res. Int. 32 (1999) 345-353.

[52] Qian J.-Y., Liu D., Huang A.-G., The efficiency of flavonoids in polar extracts of Lycium chinense Mill. fruits as free radical scavenger, Food Chem. 87 (2004) 283-288. 


\section{Influencia de diferentes tratamientos térmicos en el contenido de ácidos fenólicos en frutos seleccionados.}

Resumen - Introducción. Ya se resaltó un gran número de efectos positivos en el consumo de frutos : acción hipolipidémica, reducción del índice de glucosa en la sangre, hepatoprotección, mejora del estado antioxidante, así como, entre otros, los efectos antioxidante, antirradicalario, antiinflamatorio, anticancerígeno o antiadipogénico. Material y métodos. Se estudiaron por HPLC o detección UV los cambios de los índices de ácidos fenólicos y de sus derivados en ciertos frutos (aronia, frutilla silvestre, manzanas var. Idared y Champion, cereza, albaricoque, melocotón, frambuesa, arándano rojo y arándano) frescos o transformados. Se realizaron homogenados de frutos secados y de compotas. Asimismo, se cocieron los frutos para estimular la producción de mermeladas. Resultados y discusión. Se identificaron once ácidos fenólicos y derivados en las muestras testeadas: ácidos cafeico, clorogénico, p-cumárico, ferúlico, gálico, elágico, protocatéquico, p-hidroxibenzoico, gentísico, siríngico y vanílico. En la mayoría de los casos, el tratamiento térmico de los frutos provocó una disminución de los índices de ácidos fenólicos. En ciertas conservas, el índice de compuestos fenólicos individuales permaneció intacto o aumentó considerablemente. Conclusión. El tratamiento térmico podría tener efectos diferenciados en los índices de ácidos fenólicos en los frutos transformados, y no es posible generalizar estos efectos. En este contexto, la composición de los frutos con contenido de ácido fenólico puede variar.

Polonia / frutas / frutas en conserva / mermeladas / compotas / compuestos fenólicos / contenido fenólico 